Dear Author,

Please, note that changes made to the HTML content will be added to the article before publication, but are not reflected in this PDF.

Note also that this file should not be used for submitting corrections. 


\section{AUTHOR QUERY FORM}

\begin{tabular}{|c|c|c|}
\hline ELSEVIER & Article Number: 7359 & $\begin{array}{l}\text { Please e-mail or fax your responses and any corrections to: } \\
\text { E-mail: corrections.eseo@elsevier.tnq.co.in } \\
\text { Fax: }+31204852789\end{array}$ \\
\hline
\end{tabular}

Dear Author,

Please check your proof carefully and mark all corrections at the appropriate place in the proof (e.g., by using on-screen annotation in the PDF file) or compile them in a separate list. Note: if you opt to annotate the file with software other than Adobe Reader then please also highlight the appropriate place in the PDF file. To ensure fast publication of your paper please return your corrections within 48 hours.

For correction or revision of any artwork, please consult http://www.elsevier.com/artworkinstructions.

Any queries or remarks that have arisen during the processing of your manuscript are listed below and highlighted by flags in the proof.

\begin{tabular}{|c|l|}
\hline $\begin{array}{c}\text { Location } \\
\text { in article }\end{array}$ & \multicolumn{1}{c|}{$\begin{array}{c}\text { Query / Remark: Click on the Q link to find the query's location in text } \\
\text { Please insert your reply or correction at the corresponding line in the proof }\end{array}$} \\
\hline Q1 & $\begin{array}{l}\text { Please check the hierarchy of the section headings. } \\
\text { Q2 }\end{array}$ \\
\cline { 2 - 2 } & $\begin{array}{l}\text { Please confirm that given names and surnames have been identified correctly. } \\
\text { your approval if you have no } \\
\text { corrections to make to the PDF file }\end{array}$ \\
\hline
\end{tabular}

Thank you for your assistance. 
Design and synthesis of pironetin analogue/combretastatin A-4 hybrids containing a 1,2,3-triazole ring and evaluation of their cytotoxic activity

Concepción Vilanova, Sandra Torijano-Gutiérrez, Santiago Díaz-Oltra, Juan Murga*, Eva Falomir, Miguel Carda, J. Alberto Marco*

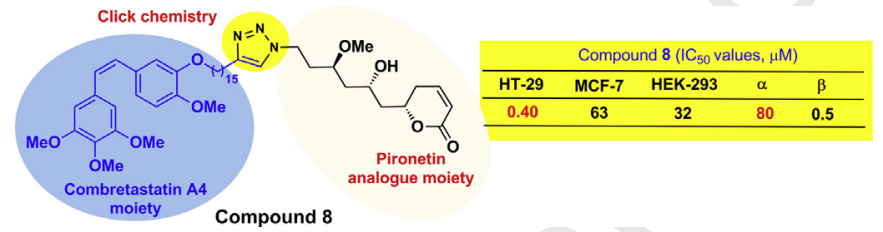

\section{Highlights}

- Hybrid molecules with combretastatin A-4 and pironetin-like moieties were prepared.

- Both moieties are connected by a variable spacer containing a 1,2,3-triazole ring.

- The molecules were tested for cytotoxicity on a normal and two tumoral cell lines.

- Some of the compounds show $\mathrm{IC}_{50}$ values similar to those of combretastatin A-4.

- $\mathrm{IC}_{50}$ values suggest that tubulin binding takes place through the combretastatin end. 
Original article

\title{
Design and synthesis of pironetin analogue/combretastatin A-4 hybrids containing a 1,2,3-triazole ring and evaluation of their cytotoxic activity
}

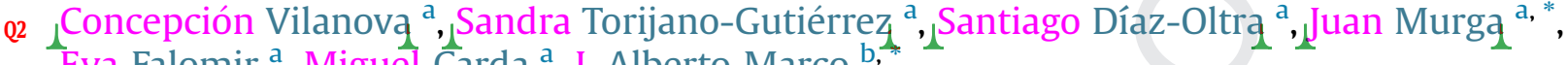

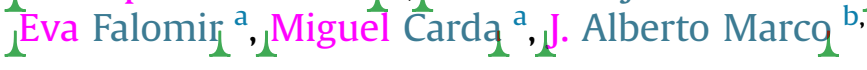 \\ a Depart. de Q. Inorgánica y Orgánica, Univ. Jaume I, E-12071 Castellón, Spain

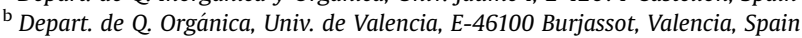

\section{A R T I C L E I N F O}

\section{Article history:}

Received 18 June 2014

Received in revised form

12 September 2014

Accepted 14 September 2014

Available online $\mathrm{xxx}$

\section{Keywords:}

Combretastatin A-4

Pironetin analogues

Hybrid molecules

Click reaction

Tubulin-active compounds

Cytotoxicity

\begin{abstract}
A B S T R A C T
We here describe the preparation of a series of hybrid molecules containing a combretastatin A-4 moiety and a pironetin analogue fragment connected through a spacer of variable length which includes a 1,2,3triazole ring. The cytotoxic activities of these compounds have been measured. Relations between structure and cytotoxicity are discussed. Some of the tested compounds showed cytotoxicity values of the same order of magnitude as combretastatin A-4 and were less toxic than the latter compound for normal cells.
\end{abstract}

(C) 2014 Published by Elsevier Masson SAS.

\section{Introduction}

It is widely known that cancer, one leading cause of death in developed countries [1], may be induced by a plethora of both external and internal factors, including genetic mutations. Accordingly, a number of types of therapeutic attack has been investigated [2,3]. One of these involves the use of cytotoxic drugs, which exert their effect in many cases by means of inducing various mechanisms of cell death [4]. As a matter of fact, many such drugs owe this property to interaction with the microtubule network. Microtubules are dynamic polymers that play a central role in a number of cellular processes, most particularly cell division, as they are key constituents of the mitotic spindle. Microtubules are constituted of a protein named tubulin, the functional form of which, and the main component, is a heterodimer formed through non-covalent binding of two monomeric constituents, called $\alpha$ - and $\beta$-tubulin. For cell division to occur in a normal way, microtubules

\footnotetext{
* Corresponding authors.

E-mail addresses: jmurga@qio.uji.es (J. Murga), alberto.marco@uv.es (J. Alberto Marco).

must be in a constant state of formation and disruption, a process named microtubule dynamic instability [5]. Any molecule which influences microtubule instability will also influence the cell division process, not only of normal cells but also of tumoral cells. Therefore, it is not surprising that tubulin-binding molecules (TBMs) constitute a very important class of anticancer agents.

TBMs may be divided in two broad categories, those that bind to $\alpha$-tubulin and those that bind to $\beta$-tubulin. The latter group is presently by far the most numerous and contains products which cause either disruption or stabilization of microtubules. Among the drugs that belong to this group, the well-known colchicine [6] and the combretastatins [7] (Fig. 1) exert their effects by causing disruption of microtubules. In contrast, another important representative of the same group, paclitaxel, was the first-described tubulin-binding drug that was found to stabilize microtubules [8]. Even though they display opposite effects, these drugs are known to bind to $\beta$-tubulin, whenever to different sites within this protein subunit [9-11].

The number of products that bind to $\alpha$-tubulin is very small, the naturally occurring 5,6-dihydro- $\alpha$-pyrone pironetin being the firstreported example [12], followed a short time later by the peptide- 
<smiles>COc1cc2c(c(OC)c1OC)-c1ccc(OC)c(=O)cc1[C@@H](N)CC2</smiles><smiles>[R20]c1c(/C=C\c2cc(OC)c(OC)c(OC)c2)ccc(OC)c1[R]</smiles>

Combretastatin A-1 $\quad \mathrm{R}_{1}=\mathrm{OH} \quad \mathrm{R}_{2}=\mathrm{H}$ Combretastatin A-4 $\quad \mathrm{R}_{1}=\mathrm{R}_{2}=\mathrm{H}$

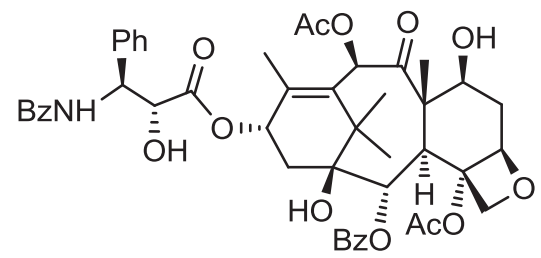

Paclitaxel

Fig. 1. Structures of some natural products reported to selectively bind to $\beta$-tubulin.

like hemiasterlin family [13] (Fig. 2). Pironetin is a potent inhibitor of tubulin assembly and has been found to arrest cell cycle progression in the G2/M phase [14].

Some structure activity relationship (SAR) studies on pironetin have been reported. These studies have shown that the presence of the conjugated $\mathrm{C} 2-\mathrm{C} 3$ double bond and of the hydroxyl group at C9 , either free or methylated, are essential for the biological activity. The presence of a (7R)-hydroxyl group might also be relevant. It has been suggested that a nucleophilic residue, yet to be conclusively identified, of the $\alpha$-tubulin chain adds in a Michael fashion to the conjugated double bond of pironetin [14], therefore forming a covalent bond with C-3 of the dihydropyrone ring [15].

The emergence of resistances to existing drugs has led to a continuous need of developing new bioactive compounds that overcome such problems. Even though first observed in the case of antibiotics [16], resistances have been reported to therapies with various types of anticancer agents [17]. The investigation of new compounds with such biological properties therefore constitutes an important goal in chemistry and pharmacology.

\section{Concept and design of hybrid tubulin-binding ligands}

As a member of the up to now small group of TBMs that bind to $\alpha$-tubulin, pironetin constitutes a pharmacologically interesting target. Not surprisingly, an appreciable number of total syntheses of this natural compound has appeared in the literature [18]. In order to develop SAR studies based upon the pironetin framework, we designed two years ago [5a] a simplified model structure where all elements that had not yet proven to be essential for the biological activity were removed. The target structures $\mathbf{I} / \mathbf{I I}$ are schematically shown in Fig. 3. The elements that were maintained are the conjugated dihydropyrone ring and the side chain with the methoxy group at C-9. The hydroxyl group at C-7 was removed in some substrates (I) and retained in others (II), in order to see its influence on the activity. All alkyl pendants (methyl groups at C-8 and C-10, ethyl at $\mathrm{C}-4$ ) and the isolated $\mathrm{C} 12-\mathrm{C} 13$ double bond were removed. The configurations of the two/three remaining stereocentres were then varied in a systematic way. Thus, all four possible stereoisomers with general constitution I, with no hydroxyl group at C-7, were prepared. Likewise, all eight stereoisomers exhibiting general structure II, with a hydroxyl group at C-7, were synthesized [5a].

The cytotoxic activity of these analogues and their interactions with tubulin were subsequently investigated. It was found, on one hand, that analogues $\mathbf{I} / \mathbf{I I}$ were cytotoxic in the low micromolar range, about three orders of magnitude less active than the parent molecule. On the other hand, we also found that they behave in the same way as pironetin, share the mechanism of action of the natural compound and compete for the same binding site in $\alpha$-tubulin. As observed for the parent compound, they also lead to disruption of the microtubule network [5a].

With the aim at extending our project, our idea was to prepare cytotoxic TBMs with a dual ability to bind to either the $\alpha$ - or the $\beta$ tubulin subunits [19] and exert a microtubule-destabilizing effect. Since these properties are specifically exhibited by pironetin (binds to $\alpha$-tubulin) and combretastatin A-4 (binds to $\beta$-tubulin), respectively, we decided to prepare compounds with a hybrid structure [20] such as $\mathbf{1}-\mathbf{8}$ (Fig. 4). These molecules display a moiety of combretastatin $\widehat{A}-4$ (itself numbered as $\mathbf{1 3}$ in Fig. 4) and another of the simplified pironetin type (14, ent-14 and $\mathbf{1 5})$, connected in turn by a spacer of variable length containing a 1,2,3-triazole ring generated by means of a "click-type reaction" [21]. Such heterocyclic rings are known to exhibit pharmacologically interesting<smiles>C/C=C/C=C/C(C)C(OC)[C@@H](C)[C@@H](O)C[C@H]1OC(=O)C=C[C@@H]1CC</smiles><smiles></smiles>

\section{Hemiasterlin}

Fig. 2. Structure of two natural products reported to selectively bind to $\alpha$-tubulin.

features that are beyond a mere connecting role [22] and, for example, may act as peptide isosters [21]. Some of the hybrid<smiles>CO[C@H]([18OH])CCC[C@H]1CC=CC(=O)O1</smiles>

I<smiles>CO[C@H]([14CH3])C[C@@H](O)C[C@@H]1CC=CC(=O)O1</smiles>

II
Fig. 3. General structures of simplified pironetin analogues of the first generation ([5a]). 
<smiles>COc1ccc(/C=C\c2cc(OC)c(OC)c(OC)c2)cc1ONc1cn(CCCCC[C@@H]2CC=CC(=O)O2)nn1</smiles>

$3 n=10 \quad 4 n=15$<smiles>COc1ccc(/C=C\c2cc(OC)c(OC)c(OC)c2)cc1O[Ga]c1cn(CC[C@H](O)C[C@@H](O)C[C@@H]2CC=CC(=O)O2)nn1</smiles>

$7 \mathrm{n}=10 \quad 8 \mathrm{n}=15$<smiles>COc1ccc(/C=C\c2cc(OC)c(OC)c(OC)c2)cc1O</smiles>

13<smiles>COc1ccc(/C=C\c2cc(OC)c(OC)c(OC)c2)cc1ONc1cn(CCCCCC2CC=CC(=O)O2)nn1</smiles>

ent-1 $n=3 \quad$ ent-2 $n=7$ ent $-3 \mathrm{n}=10$ ent $-4 \mathrm{n}=15$<smiles>C#CCOc1cc(/C=C\c2cc(OC)c(OC)c(OC)c2)ccc1OC</smiles>

$10 n=7$

$11 \mathrm{n}=10$<smiles>NCCCCC[C@H]1CC=CC(=O)O1</smiles>
ent-14 $5 \alpha \mathrm{H}$<smiles>CO[C@H](CCN)C[C@@H](O)C[C@@H]1CC=CC(=O)O1</smiles>

15

Fig. 4. Structures of the pironetin analogue/combretastatin A-4 hybrids used in this study (1-8) and of their synthetic precursors (9-15), including combretastatin A-4 (13).

molecules ( $\mathbf{1}$ to $\mathbf{4}$ and ent-1 to ent-4) have been prepared in both antipodal forms [23].

\section{Synthetic work}

Combretastatin A-4 (13) was prepared according to a literature procedure [24]. Its $O$-alkyl derivatives $\mathbf{9} \mathbf{1 2}$ were prepared as depicted in Scheme 1 by means of alkylation with $\omega$-haloalkynes 1619 (for experimental details, see the Supporting Information).

The synthesis of the pironetin fragments 14, ent-14 and 15 was performed as depicted in Scheme 2. Thus, the known pyrones $\mathbf{2 0}$, ent-20 and 22, prepared according to the general concept used in our previous papers [5a,b], were first tosylated to, respectively, 21, ent-21 and 23. Treatment of the latter compounds with sodium

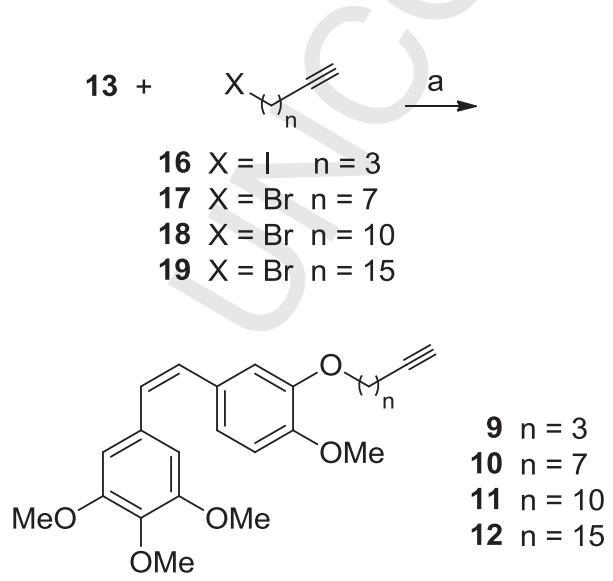

Scheme 1. Synthesis of $O$-alkylated combretastatin A-4 derivatives $9-12$ : (a) $\mathrm{K}_{2} \mathrm{CO}_{3}$, DMF, 24 h, r.t. (yields: 9, 83\%; 10, 82\%; 11, 83\%; 12, 88\%). Acronyms and abbreviations: DMF, $N, N$-dimethylformamide. azide in DMF furnished dihydropyrones $\mathbf{1 4}$, ent-14 and 24. Desilylation of the latter gave $\mathbf{1 5}$ [23].

Heating acetylenic compounds $9-12$ with the aforementioned dihydropyrones under copper(I) catalysis gave rise to a 1,3-dipolar cycloaddition [21] with regioselective formation of the desired 1,2,3-triazoles $\mathbf{1}$ to $\mathbf{4}$, ent-1 to ent-4 and $\mathbf{5}$ to $\mathbf{8}$ (Scheme 3).

After the synthesis of the hybrid molecules was completed, the compounds were investigated in relation to their cytotoxic activity towards two types of tumoral cell lines and one normal cell line.

\section{Biological work}

\subsection{Cellular effects of the compounds}

\subsubsection{Cytoxicity values}

We carried out a measurement of the cytotoxicity of the synthetic combretastatin A-4 derivatives 1-4 and their respective enantiomers (ent-1 to ent-4), and $\mathbf{5} \rightarrow \mathbf{8}$. Cytotoxicity assays were performed as described in the Experimental Section using two types of tumoral cells, the human colon adenocarcinoma HT-29 and the breast adenocarcinoma MCF-7 cell lines. In addition, one normal cell line, the human embryonic kidney cell line (HEK-293) [25] was employed in the assays for comparison. Cytotoxicity values, expressed as the compound concentration $(\mu \mathrm{mol} / \mathrm{L})$ that causes $50 \%$ inhibition of cell growth ( $\mathrm{IC}_{50}$ ), are shown in Table 1.

The observed values are in the medium to low micromolar range. Compounds 2, 3, ent-1, ent-4, 6 and most particularly 8 showed the highest cytotoxicities for the HT-29 cell line, with $\mathrm{IC}_{50}$ values which were not very different of (in the case of $\mathbf{8}$ visibly lower than) those of combretastatin A-4 for this particular cell line. In the case of the MCF-7 cell line, the lowest $\mathrm{IC}_{50}$ value, not very different of that of combretastatin A-4, was shown by compound $\mathbf{6}$, followed by ent-3. A further aspect also worth mentioning is the 

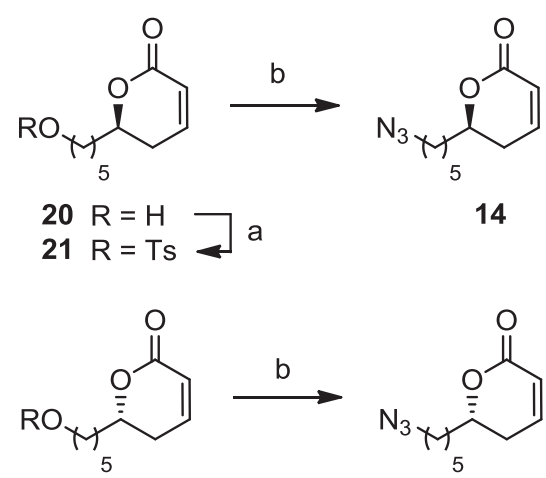

ent-20 $\mathrm{R}=\mathrm{H} \longrightarrow$ ent -14

$\begin{array}{ll}\text { ent-21 } & \mathrm{R}=\mathrm{Ts}\end{array}$ a
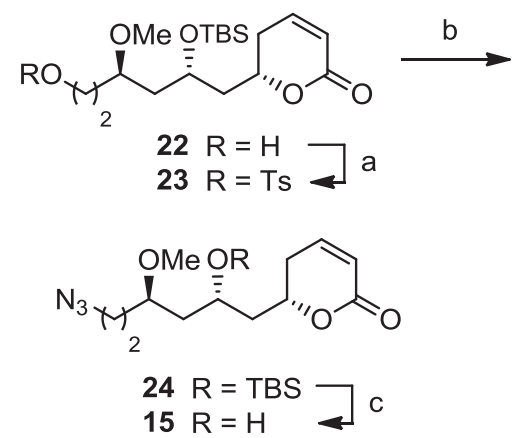

Scheme 2. Synthesis of azides 14, ent-14 and 15: (a) TsCl, Et $3 \mathrm{~N}, \mathrm{DMAP}, \mathrm{CH}_{2} \mathrm{Cl}_{2}, 3-4 \mathrm{~h}$, r.t. (21: $83 \%$; ent-21: $84 \%$; 23: 80\%); (b) $\mathrm{NaN}_{3}$, DMF, 3-4 h, r.t. (14: 85\%; ent-14: 85\%; 24, $82 \%)$; (c) $48 \%$ aq HF, MeCN, 4 h, r.t. (95\%). Acronyms and abbreviations: Ts, $p$-toluenesulfonyl; DMAP, 4-( $N, N$-dimethylamino)pyridine; TBS, $t$-butyldimethylsilyl.

fact that some of the synthetic compounds are more toxic for one or the other tumoral cell type than for normal cells, a desirable feature. This can be better appreciated with the $\alpha$ and $\beta$ coefficients, obtained by dividing the $\mathrm{IC}_{50}$ values of the normal cell line (HEK293) by those of one or the other tumoral cell line (see footnote in the Table). The higher value of either the $\alpha$ or the $\beta$ coefficient, the higher the safety margin of the compound in the corresponding cell line. Thus, combretastatin A-4 itself showed good values of both coefficients, most particularly in the case of the MCF-7 cell line. Pironetin, with $\mathrm{IC}_{50}$ values in the low nanomolar range, showed similar values for the HT-29 and the MCF-7 cell lines. Among the compounds with an appreciable cytotoxicity (low $\mathrm{IC}_{50}$ values), ent$\mathbf{1 , 6}$ and $\mathbf{8}$ are worth mentioning as they exhibit good $\alpha$ values, with that of $\mathbf{8}$ being particularly high. Compound $\mathbf{6}$ also show a good $\beta$ value.

Some aspects related to the relation between the structures and the observed cytotoxicity deserve comment. In the case of two subsets of hybrid molecules [20] where there are differences between in the carbon chain length (e.g. 1-4 and 5-8), differences in the degree of cytotoxicity are also observed but no obvious relation between both features are perceived. Thus, for compounds $1-4$, which display a very simplified pironetin moiety, the lowest $\mathrm{IC}_{50}$ values are found for the two compounds that have the intermediate values of the spacer carbon chain length $(2, n=7$ and $3, n=10)$. As for the compounds of the enantiomeric series (ent-1 to ent-4), their cytotoxicities are not very different from those of 1-4. However, for compounds $5 \mathbf{8}$, which display a more complex pironetin part, the lowest $\mathrm{IC}_{50}$ value is clearly that of the compound with the longest spacer carbon chain $(\mathbf{8}, n=15)$. It is difficult to propose now an explanation for this fact, as we do not yet know whether these compounds are interacting with tubulin at the pironetin site $(\alpha-$ tubulin) or else at the combretastatin A-4 site ( $\beta$-tubulin). The fact that the $\mathrm{IC}_{50}$ values of the hybrid molecules are much more similar to those of combretastatin A-4 than to those of pironetin suggests that these compounds are possibly interacting with tubulin through the combretastatin A- 4 site at $\beta$-tubulin. If this is true, one would conclude that the reversible non-covalent interaction at the $\beta$-tubulin site is kinetically faster than the covalent irreversible union at the $\alpha$-tubulin site. More research in this direction will be necessary in order to definitively clarify this and other issues, such as the possible influence of the triazole fragment [26].

\section{Summary and conclusions}

We have prepared a set of synthetic hybrid molecules containing a combretastatin A-4 moiety and a fragment structurally related to the natural product pironetin. The two structural moieties have been connected through a spacer of variable length containing a 1,2,3-triazole ring, generated in turn by means of a 1,3-dipolar cycloaddition ("click reaction"). Some of these molecules have been synthesized in both enantiomeric forms. Their cytotoxic action (IC 50 values) towards a normal (HEK-293) and two tumoral (HT-29 and MCF-7) cell lines has then been measured. Several of the synthetic derivatives proved cytotoxic towards at least one of the two tumoral cell lines, with some of them showing cytotoxic activities of the same order as combretastatin A-4. For some compound/cell line combinations, most particularly 8 and the HT-29 cell line, the normal vs. tumoral cytotoxicity ratio was higher than in the case of the aforementioned natural product, that is, they proved comparatively much less cytotoxic towards normal cells (these compounds are highlighted in Table 1). This feature may potentially show pharmacological interest.

\section{Experimental}

\subsection{Chemistry}

\subsubsection{General procedures}

The general reaction conditions and the physical and spectral data of all synthetic intermediates and final compounds are described in detail in the Supporting Information. The samples of compounds used for the biological studies were purified to $>95 \%$ by means of preparative HPLC.

\subsection{Biological studies}

\subsubsection{Materials and methods}

6.2.1.1. Reagents and cell culture. Cell culture media were purchased from Gibco (Grand Island, NY, USA). Fetal bovine serum (FBS) was a product of Harlan-Seralab (Belton, U.K.). Supplements and other chemicals not listed in this section were obtained from Sigma Chemicals Co. (St. Louis, Mo., USA). Plastics for cell culture were supplied by Thermo Scientific ${ }^{\mathrm{TM}}$ BioLite. All tested compounds were dissolved in DMSO at a concentration of $10 \mu \mathrm{g} / \mathrm{mL}$ and stored at $-20^{\circ} \mathrm{C}$ until use.

Cell lines were maintained in Dulbecco's modified Eagle's medium (DMEM) containing glucose $(1 \mathrm{~g} / \mathrm{L})$, glutamine $(2 \mathrm{mM})$, penicillin $(50 \mathrm{IU} / \mathrm{mL})$, streptomycin $(50 \mu \mathrm{g} / \mathrm{mL})$ and amphoterycin $(1.25 \mu \mathrm{g} / \mathrm{mL})$, supplemented with $10 \%$ FBS.

\subsubsection{Cytotoxicity assays}

The 3-(4,5-dimethylthiazol-2-yl)-2,5-diphenyltetrazolium bromide (MTT; Sigma Chemical Co., St. Louis, MO) dye reduction assay in 96-well microplates was used, as previously described [27]. 


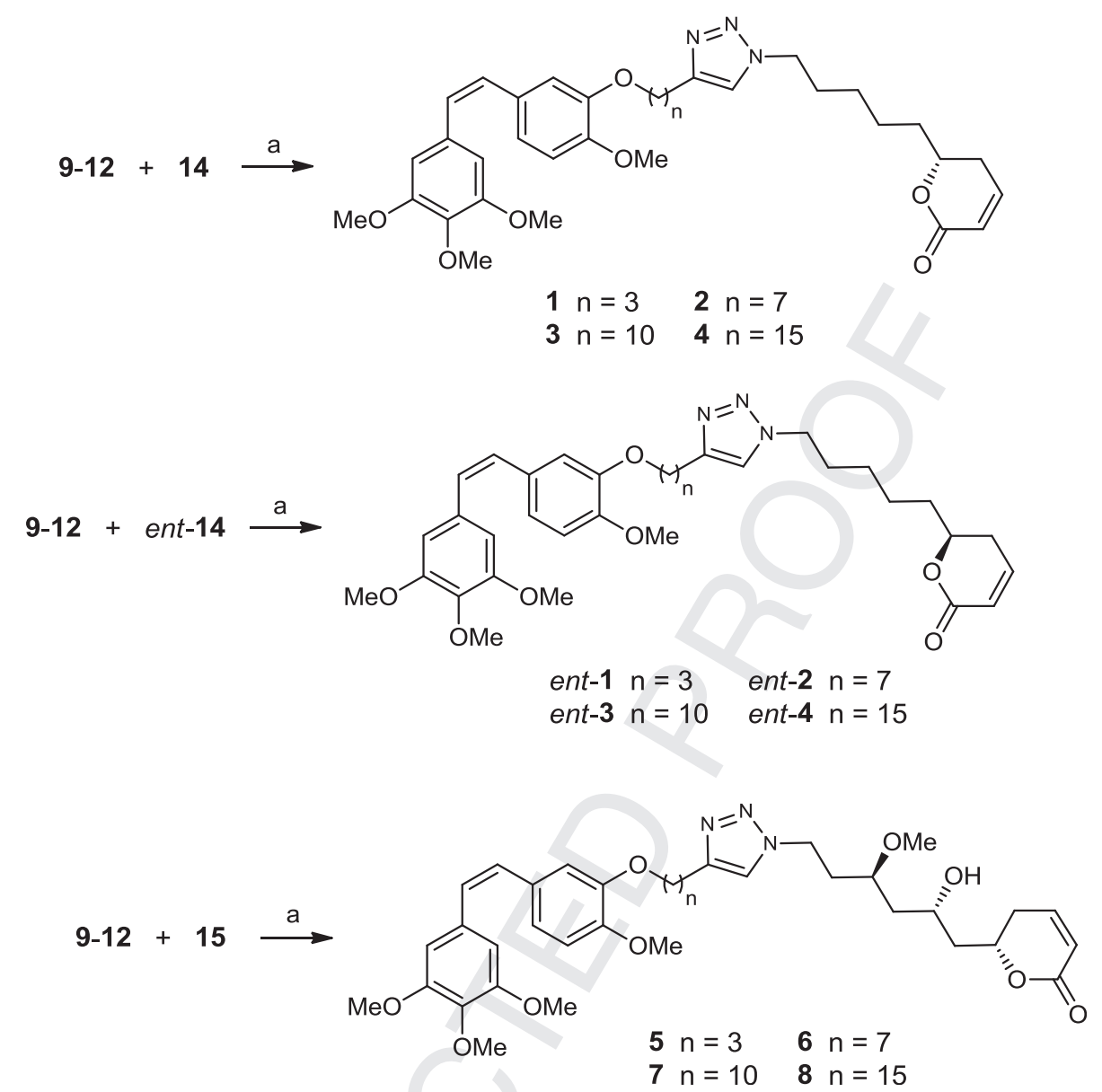

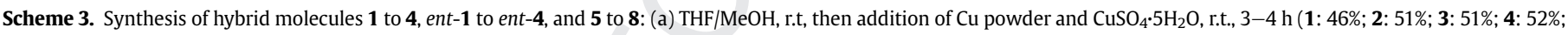
ent-1: 50\%; ent-2: 55\%; ent-3: 58\%; ent-4: 52\%; 5: 55; 6: 58\%; 7: 53\%; 8: 55\%).

Some $5 \times 10^{3}$ cells of HT-29, MCF-7 or HEK-293 cells in a total

Table 1

Cytotoxicity of pironetin analogue/combretastatin A-4 hybrids $1-8$ and ent-1 to ent4.

\begin{tabular}{lccccc}
\hline Compound & HT-29 & MCF-7 & HEK-293 & $\alpha^{\mathrm{b}}$ & $\beta^{\mathrm{c}}$ \\
\hline CoA4 & $4.2 \pm 0.5$ & $1 \pm 0.2$ & $25 \pm 3$ & 5.9 & 25 \\
Pironetin & $0.0064 \pm 0.0007$ & $0.006 \pm 0.002$ & $0.017 \pm 0.001$ & 2.6 & 2.8 \\
$\mathbf{1}$ & $40 \pm 2$ & $40 \pm 0.3$ & $1.7 \pm 0.3$ & 0.04 & $<0.1$ \\
$\mathbf{2}$ & $8 \pm 1$ & $39 \pm 3$ & $9.3 \pm 0.2$ & 1.2 & $<0.1$ \\
$\mathbf{3}$ & $9 \pm 1$ & $29 \pm 6$ & $4.5 \pm 0.3$ & 0.5 & 0.2 \\
$\mathbf{4}$ & $22 \pm 3$ & $66 \pm 4$ & $16 \pm 1$ & 0.7 & 0.2 \\
ent-1 & $\mathbf{9 . 3} \pm \mathbf{0 . 8}$ & $20 \pm 5$ & $34 \pm 10$ & $\mathbf{3 . 7}$ & 1.7 \\
ent-2 & $\mathbf{1 1} \pm \mathbf{1}$ & $32 \pm 4$ & $40 \pm 1$ & $\mathbf{3 . 6}$ & 1.2 \\
ent-3 & $17.5 \pm 0.1$ & $13 \pm 3$ & $13 \pm 3$ & 0.7 & 1 \\
ent-4 & $8 \pm 3$ & $37 \pm 3$ & $2.6 \pm 1.3$ & 0.3 & $<0.1$ \\
$\mathbf{5}$ & $24.0 \pm 0.2$ & $23 \pm 6$ & $30 \pm 5$ & 1.2 & 1.3 \\
$\mathbf{6}$ & $8 \pm 1$ & $7 \pm 2$ & $21 \pm 4$ & 2.6 & 3 \\
$\mathbf{7}$ & $17.3 \pm 0.4$ & $20 \pm 3$ & $40 \pm 5$ & 2.3 & 2 \\
$\mathbf{8}$ & $\mathbf{0 . 4 0} \pm \mathbf{0 . 0 5}$ & $63 \pm 2$ & $32 \pm 10$ & $\mathbf{8 0}$ & 0.5 \\
\hline
\end{tabular}

${ }^{\mathrm{a}} \mathrm{IC}_{50}$ values, which include those of the parent compounds combretastatin A-4 (CoA4) and pironetin, are expressed as the compound concentration $(\mu \mathrm{mol} / \mathrm{L}$ or $\mu \mathrm{M})$ that causes $50 \%$ inhibition of cell growth. The values are the average ( \pm s.d.) of three different measurements performed as described in the Material and Methods section.

${ }^{\text {b }} \alpha=\mathrm{IC}_{50}(\mathrm{HEK}-293) / \mathrm{IC}_{50}(\mathrm{HT}-29)$.

c $\beta=\mathrm{IC}_{50}$ (HEK-293)/IC $\mathrm{I}_{50}$ (MCF-7). Values of $\alpha$ and $\beta$ have been rounded off to a decimal figure. Compounds with both high cytotoxicity towards one tumoral cell line and comparatively low cytotoxicity towards the normal cell line have been highlighted in boldface italics. volume of $100 \mu \mathrm{L}$ of their respective growth media were incubated with serial dilutions of the tested compounds. After 3 days of incubation $\left(37{ }^{\circ} \mathrm{C}, 5 \% \mathrm{CO}_{2}\right.$ in a humid atmosphere), $10 \mu \mathrm{l}$ of MTT ( $5 \mathrm{mg} / \mathrm{ml}$ in PBS) were added to each well and the plate was incubated for further $4 \mathrm{~h}\left(37^{\circ} \mathrm{C}\right)$. The resulting formazan was dissolved in $150 \mu \mathrm{L}$ of $0.04 \mathrm{~N} \mathrm{HCl} / 2$-propanol and read at $550 \mathrm{~nm}$. All determinations were carried out in triplicate.

\section{Acknowledgments}

Financial support has been granted by the Spanish Government (MINECO, Ministerio de Economía y Competitividad, projects CTQ2008-02800 and CTQ2011-27560), by the Consellería d'Empresa, Universitat i Ciencia de la Generalitat Valenciana (projects PROMETEO/2013/027, ACOMP09/113 and ACOMP/2014/272) and by the Universitat Jaume I (projects P1-1B-2008-14 and PI-1B2011-37). S.T.-G. thanks the Generalitat Valenciana for a predoctoral fellowship of the Santiago Grisolía program. C.V. thanks the MINECO for a predoctoral fellowship of the FPI program. J.A.M. thanks the COST Action CM0804 for aid in establishing collaborations with other research groups. We further thank Prof. C.M. Cerda García-Rojas, from the Departamento de Química, Centro de Investigación y de Estudios Avanzados del Instituto Politécnico Nacional, Mexico, for the kind sending of pironetin samples. 


\section{Appendix A. Supplementary data}

Supplementary data related to this article can be found at http:// dx.doi.org/10.1016/j.ejmech.2014.09.053.

\section{References}

[1] M. Garcia, A. Jemal, E.M. Ward, M.M. Center, Y. Hao, R.L. Siegel, M.J. Thun, Global Cancer Facts \& Figures 2007, American Cancer Society, Atlanta, GA, 2007.

[2] (a) D. Hanahan, R.A. Weinberg, Cell 100 (2000) 57-70;

(b) M.R. Stratton, P.J. Campbell, P.A. Futreal, Nature 458 (2009) 719-724;

(c) D. Hanahan, R.A. Weinberg, Cell 144 (2011) 646-674.

[3] (a) F.T. Boyle, G.F. Costello, Chem. Soc. Rev. 27 (1998) 251-261;

(b) J.B. Gibbs, Science 287 (2000) 1969-1973.

[4] (a) L.Z. Penn, Curr. Opin. Invest. Drugs 2 (2001) 684-692;

(b) B. Zhou, Z.-L. Liu, Pure Appl. Chem. 77 (2005) 1887-1903;

(c) H.-J. Park, H.-J. Jung, K.-T. Lee, J. Choi, Nat. Prod. Sci. 12 (2006) 175-192; (d) L. Portt, G. Norman, C. Clapp, M. Greenwood, M.T. Greenwood, Biochim. Biophys. Acta 1813 (2011) 238-259;

(e) F. Torres-Andón, B. Fadeel, Acc. Chem. Res. 46 (2013) 733-742.

[5] For additional comments on tubulin structure and function, see our previous papers in this area: (a) J.A. Marco, J. García-Pla, M. Carda, J. Murga, E. Falomir, C. Trigili, S. Notararigo, J.F. Díaz, I. Barasoain, Eur. J. Med. Chem. 46 (2011) 1630-1637;

(b) M. Carda, J. Murga, S. Díaz-Oltra, J. García-Pla, J. Paños, E. Falomir, C. Trigili, J.F. Díaz, I. Barasoain, J.A. Marco, Eur. J. Org. Chem. (2013) 1116-1123;

(c) M. Carda, J. Murga, J. Paños, C.A. Angulo-Pachón, J. García-Pla, S. Díaz-Oltra, J.A. Marco, C. Trigili, M. Redondo-Horcajo, J.F. Díaz, I. Barasoain, Curr. Med. Chem. 20 (2013) 1173-1182;

(d) J. Paños, S. Díaz-Oltra, M. Sánchez-Peris, J. García-Pla, J. Murga, E. Falomir, M. Carda, M. Redondo-Horcajo, J.F. Díaz, I. Barasoain, J.A. Marco, Org. Biomol. Chem. 11 (2013) 5809-5826.

[6] J. Chen, T. Liu, X. Dong, Y. Hu, Mini-Rev. Med. Chem. 9 (2009) 1174-1190.

[7] (a) A. Cirla, J. Mann, Nat. Prod. Rep. 20 (2003) 558-564;

(b) V. Srivastava, A.S. Negi, J.K. Kumar, M.M. Gupta, S.P.S. Khanuja, Bioorg. Med. Chem. 13 (2005) 5892-5908;

(c) G.U. Dachs, A.J. Steele, C. Coralli, C. Kanthou, A.C. Brooks, S.P. Gunningham, M.J. Currie, A.I. Watson, B.A. Robinson, G.M. Tozer, BMC Cancer 6 (2006) 280-290;

(d) G.C. Tron, T. Pirali, G. Sorba, F. Pagliai, S. Busacca, A.A. Genazzani, J. Med. Chem. 49 (2006) 3033-3044;

(e) Y. Shan, J. Zhang, Z. Liu, M. Wang, Y. Dong, Curr. Med. Chem. 18 (2011) $523-538$.

[8] Y. Fu, S. Li, Y. Zu, G. Yang, Z. Yang, M. Luo, S. Jiang, M. Wink, T. Efferth, Curr. Med. Chem. 16 (2009) 3966-3985.

[9] (a) M.A. Jordan, Curr. Med. Chem. - Anticancer Drugs 2 (2002) 1-17;

(b) M. Abal, J.M. Andreu, I. Barasoain, Curr. Cancer Drug Targets 3 (2003) 193-203.

[10] (a) J.J. Correia, S. Lobert, Curr. Pharm. Des. 7 (2001) 1213-1228;

(b) J. Jiménez-Barbero, F. Amat-Guerri, J.P. Snyder, Curr. Med. Chem. - Anticancer Drugs 2 (2002) 91-122;

(c) J.F. Díaz, J.M. Andreu, J. Jiménez-Barbero, Top. Curr. Chem. 286 (2009) 121-149;

(d) B. Gigant, A. Cormier, A. Dorléans, R.B.G. Ravelli, M. Knossow, Top. Curr. Chem. 286 (2009) 259-278;

(e) E.M. Daly, R.E. Taylor, Curr. Chem. Biol. 3 (2009) 367-379.

[11] (a) V.M. Sánchez-Pedregal, C. Griesinger, Top. Curr. Chem. 286 (2009) 151-208;

(b) J.H. Nettles, K.H. Downing, Top. Curr. Chem. 286 (2009) 209-257;

(c) M. Botta, S. Forli, M. Magnani, F. Manetti, Top. Curr. Chem. 286 (2009) 279-328.

[12] F. Sarabia, M. García-Castro, A. Sánchez-Ruiz, Curr. Bioact. Comp. 2 (2006) 269-299.

[13] H.J. Anderson, J.E. Coleman, R.J. Andersen, M. Roberge, Cancer Chemother. Pharmacol. 39 (1997) 223-226.

[14] (a) M. Kondoh, T. Usui, S. Kobayashi, K. Tsuchiya, K. Nishikawa, T. Nishikiori, T. Mayumi, H. Osada, Cancer Lett. 126 (1998) 29-32;

(b) M. Kondoh, T. Usui, T. Nishikiori, T. Mayumi, H. Osada, Biochem. J. 340 (1999) 411-416;

(c) H. Watanabe, H. Watanabe, T. Usui, M. Kondoh, H. Osada, T. Kitahara, J. Antibiot. 53 (2000) 540-545;

(d) T. Usui, H. Watanabe, H. Nakayama, Y. Tada, N. Kanoh, M. Kondoh, T. Asao,
K. Takio, H. Watanabe, K. Nishikawa, T. Kitahara, H. Osada, Chem. Biol. 11 (2004) 799-806.

[15] For two recent reviews on chemical and pharmacological aspects of 5,6dihydropyran-2-ones, see: (a) J.A. Marco, M. Carda, J. Murga, E. Falomir, Tetrahedron 63 (2007) 2929-2958;

(b) J.A. Marco, M. Carda, in: T. Janecki (Ed.), Natural Lactones and Lactams. Synthesis, Occurrence and Biological Activity, Wiley-VCH, 2014, pp. 51-100.

[16] (a) L.M. Rossi, P. Rangasamy, J. Zhang, X.-Q. Qiu, G.Y. Wu, J. Pharm. Sci. 97 (2007) 1060-1070;

(b) P. Courvalin, J. Intern. Med. 264 (2008) 4-16;

(c) M. Gualtieri, F. Baneres-Roquet, P. Villain-Guillot, M. Pugniere, J.P. Leonetti, Curr. Med. Chem. 16 (2009) 390-393.

[17] (a) M. Kavallaris, Nat. Rev. Cancer 10 (2010) 194-204;

(b) C. Holohan, S. Van Schaeybroeck, D.B. Longley, P.G. Johnston, Nat. Rev. Cancer 13 (2013) 714-726.

[18] (a) K. Yasui, Y. Tamura, K. Nakatani, K. Kawada, M. Ohtani, J. Org. Chem. 60 (1995) 7567-7574;

(b) M.K. Gurjar, J.T. Henri Jr., D.S. Bose, A.V.R. Rao, Tetrahedron Lett. 37 (1996) 6615-6618:

(c) N. Chida, M. Yoshinaga, T. Tobe, S. Ogawa, Chem. Comm. (1997) 1043-1044;

(d) H. Watanabe, H. Watanabe, M. Bando, M. Kido, T. Kitahara, Tetrahedron 55 (1999) 9755-9776;

(e) G.E. Keck, C.E. Knutson, S.A. Wiles, Org. Lett. 3 (2001) 707-710;

(f) L.C. Dias, L.G. de Oliveira, M.A. de Sousa, Org. Lett. 5 (2003) 265-268;

(g) X. Shen, A.S. Wasmuth, J. Zhao, C. Zhu, S.G. Nelson, J. Am. Chem. Soc. 128 (2006) 7438-7439;

(h) D. Enders, S. Dhulut, D. Steinbusch, A. Herrbach, Chem. Eur. J. 13 (2007) 3942-3949;

(i) C. Bressy, J.-P. Vors, S. Hillebrand, S. Arseniyadis, J. Cossy, Angew. Chem. Int Ed. 47 (2008) 10137-10140;

(j) M.T. Crimmins, A.-M.R. Dechert, Org. Lett. 11 (2009) 1635-1638;

(k) J.S. Yadav, H. Ather, N.V. Rao, M.S. Reddy, A.R. Prasad, Synlett (2010) 1205-1208.

[19] Even though the distance between the pironetin and the combretastatin A-4 binding sites is not yet known with accuracy, an examination of the available $X$-ray data of tubulin [10d] indicates that the carbon chains of compounds 1-8 are not sufficiently long to permit a simultaneous binding to both sites. However, we have not tried to prepare derivatives with still longer chains because this would give highly hydrophobic compounds with a too low solubility in polar media.

[20] For some selected reviews on the interest and utility of hybrid molecules in medicine and pharmacology, see: (a) S. Hanessian, ChemMedChem 1 (2006) 1300-1330;

(b) B. Meunier, Acc. Chem. Res. 41 (2008) 69-77;

(c) M. Decker, Curr. Med. Chem. 18 (2011) 1464-1475.

[21] For reviews on the various aspects of click-type reactions, see: (a) H.C. Kolb M.G. Finn, K.B. Sharpless, Angew. Chem. Int. Ed. 40 (2001) 2004-2021;

(b) H.C. Kolb, K.B. Sharpless, Drug. Discov. Today 8 (2003) 1128-1137;

(c) V.D. Bock, H. Hiemstra, J.H. van Maarseveen, Eur. J. Org. Chem. (2006) 51-68;

(d) M.V. Gil, M.J. Arévalo, Ó. López, Synthesis (2007) 1589-1620;

(e) J.E. Moses, A.D. Moorhouse, Chem. Soc. Rev. 36 (2007) 1249-1262;

(f) L. Liang, D. Astruc, Coord. Chem. Rev. 255 (2011) 2933-2945;

(g) S.G. Agalave, S.R. Maujan, V.S. Pore, Chem. - Asian J. 6 (2011) 2696-2718;

(h) J. Hou, X. Liu, J. Shen, G. Zhao, P.G. Wang, Expert Opin. Drug. Disc 7 (2012) 489-501.

[22] For recent examples of biologically active, non-hybrid combretastatin analogues which contain triazole moieties, see: (a) Ø.W. Akselsen, K. Odlo, J.J. Cheng, G. Maccari, M. Botta, T.V. Hansen, Bioorg. Med. Chem. 20 (2012) 234-242;

(b) N. Mur-Blanch, G.G. Chabot, L. Quentin, D. Scherman, S. Bourg, D. Dauzonne, Eur. J. Med. Chem. 54 (2012) 22.

[23] C. Vilanova, Ph.D. Thesis, University Jaume I, 2013.

[24] K. Gaukroger, J.A. Hadfield, L.A. Hepworth, N.J. Lawrence, A.T. McGown, J. Org. Chem. 66 (2001) 8135-8138.

[25] N. Arden, M.J. Betenbaugh, Trends Biotechnol. 22 (2004) 174-180.

[26] For a recent detailed study, including docking calculations, of interactions of tubulin with triazole-containing molecules, see: A. Carta, I. Briguglio, S. Piras, G. Boatto, P. La Colla, R. Loddo, M. Tolomeo, S. Grimaudo, A. Di Cristina, R.M. Pipitone, E. Laurini, M.S. Paneni, P. Posocco, M. Fermeglia, S. Pricl Eur. J Med. Chem. 46 (2011) 4151-4167.

[27] S. Rodríguez-Nieto, M.A. Medina, A.R. Quesada, Anticancer Res. 21 (2001) 3457-3460.
61 